Bangladesh J. Bot. 50(3): 925-932, 2021 (September) SpecialＤOI: https://doi.org/10.3329/bjb.v50i5.56446

\title{
EFFECTS OF CULTIVATING DIFFERENT CROPS ON SOIL EROSION OF SLOPE FARMLAND
}

\author{
ZHEN GUO ${ }^{1,2,3 *}$ AND JUAN LI ${ }^{1,2,3}$ \\ Institute of Land Engineering and Technology, Shaanxi Provincial Land Engineering \\ Construction Group Co. Ltd., Xi'an, Shaanxi 710075, China
}

Keywords: Soil nutrients, Planting patterns, Soil erosion, Crop yields, Different slopes

\begin{abstract}
The soil nutrient content, particle size composition, crop yield and erosion resistance were studied considering the slope farmland with different slope sizes and different crops as the research object. The results showed that the available phosphorus content was higher under the wheat planting mode. Rape planting was conducive to the accumulation of organic matter, total nitrogen and available potassium, and nutrient accumulation was more obvious when treated at $5^{\circ}$ slope. The soil texture was sandy loam under the wheat planting mode. After rapeseed planting, the soil texture began to change to silt loam. The crop yield was the highest under different planting modes at $5^{\circ}$. Rapeseed was found to increase the soil erosion resistance of sloping farmland compared with wheat, and the greater was the slope, the stronger the erosion resistance.
\end{abstract}

\section{Introduction}

Soil erosion resistance refers to the resistance of soil to the dispersion and transport of erosion force, which is also one of the important parameters to evaluate soil erosion resistance, and its magnitude mainly depends on the affinity of soil to water and the adhesive force between soil particles (Meng et al. 2021). The area of sloping farmland in China is large, and its water and soil loss account for a large proportion of the total water and soil loss (Xiang et al. 2021). The prevention and control of water and soil loss on sloping farmland are the focus of China's water and soil erosion control work (Wen et al. 2021). Therefore, the prevention and control of soil erosion on sloping farmland are a important link in the construction of China's ecological environment and the realization of sustainable development ( $\mathrm{Li}$ and Wang 2020).

Topographic conditions mainly include slope length, slope, slope type and aspect, among which slope length and slope are two important topographic factors that affect soil erosion and nutrient migration on the slope (Cerdà et al. 2021). The slope erosion research on slope length believes that the erosion intensity will increase as the slope length increases (Bircher et al. 2019). The influence of slope on soil and water loss is mainly manifested that it is closely related to slope velocity, and thus affects the initiation of soil particles, erosion mode and sediment carrying capacity of runoff (Zhang et al. 2017). At the slope scale, erosion will not only cause soil particle migration, nutrient loss, degradation of soil fertility quality and increased spatial variability, but can even significantly change the nutrient cycle process, causing problems such as sedimentation and water pollution in different places downstream (Quijanol et al. 2019). At present, there are many researches about the effects of soil erosion on soil physical and chemical properties. According to the research of Du and Du (2013), soil clay has a relatively large surface area and is an important carrier of soil moisture, soil organic matter and nutrients, and soil erosion gradually

\footnotetext{
*Author for correspondence: <675334047@qq.com>. ${ }^{1}$ Shaanxi Provincial Land Engineering Construction Group Co., Ltd., Xi' an 710075, China. ${ }^{2}$ Key Laboratory of Degraded and Unused Land Consolidation Engineering, the Ministry of Natural and Resources of China, Shaanxi, Xi' an 710075, China. ${ }^{3}$ Technology Innovation Center for Land Engineering and Human Settlements, Shaanxi Land Engineering Construction Group Co., Ltd. and Xi'an Jiaotong University, Xi' an 710049, China.
} 
reduces soil clay content. Guo et al. (2003) studied the distribution characteristics of soil nutrients on different slopes in a small watershed on the Loess Plateau, and showed that soil nutrients are characterized by enrichment of the slope toe and loss of slope and top. In addition, some scholars have shown that scientific and reasonable planting methods can reduce surface water and soil loss, increase soil infiltration, and improve soil quality (Siraj and Jemal 2017). Li et al. (2013) used outdoor sampling and indoor analysis to study the effect of forage hedge rows on soil erosion resistance of sloping farmland, and pointed out that forage grass significantly improves soil erosion resistance by improving soil physical properties and roots. Nearing et al. (2005) reported that rainfall and cover have important effects on soil erosion, but the impact of surface cover on runoff and erosion is greater than that of canopy cover.

Sloping farmland is one of the land types with the most serious soil erosion in China. It is particularly important to study the water, soil and fertilizer conservation and also local conditions that mainly prevent soil erosion on the slope farmland. Zhang et al. (2014) studied the soil erosion resistance of winter wheat after harvest through field sampling and laboratory analysis, and pointed out that wheat roots have a significant impact on soil erosion resistance. Therefore, the present study selected slope farmland with different slopes in the loess region as the test area, and followed two planting methods of wheat and rape as the research object to study their effects on the physical, chemical and erodibility of different slopes of loess. Besides initiatives were taken to analyze quantitatively these two contribution rate of planting methods to the comprehensive effect of soil. It would laid a theoretical foundation for the in-depth study of crop scientific planting patterns on sloping fields in the loess region, improvement of soil properties in the region, and prevention and control of soil erosion. It is of great significance to promote the sustainable development of mountain agriculture and ensure national food security.

\section{Materials and Methods}

The sloping farmland erosion resistance simulation test was set up in the Qinling Field Monitoring Center Station in Mei County $\left(107^{\circ} 39^{\prime}-108^{\circ} 00^{\prime} \mathrm{E}, 33^{\circ} 59^{\prime}-34^{\circ} 19^{\prime} \mathrm{N}\right)$. It belongs to the western Guanzhong Plain of Shaanxi Province, with a warm temperate continental semi-humid climate. The altitude was between $442-3767 \mathrm{~m}$, the annual average temperature was $12.9^{\circ} \mathrm{c}$, the average precipitation was $609.5 \mathrm{~mm}$, the average sunshine was $2015.2 \mathrm{hrs}$, and the frost-free period was $21 \mathrm{~d}$. The terrain of the region was complexed, generally for the north and south high, low in the middle of the asymmetric terrain. The east-west extension was slightly longer, and the north-south undulation was relatively short.

This model was designed to have a total length of $64 \mathrm{~m}$, a width of $18 \mathrm{~m}$, and an area of 1152 $\mathrm{m}^{2}$. The model had 4 main test areas. Each test area was a rectangle with a length of $14 \mathrm{~m}$ and a width of $12 \mathrm{~m}$, with slopes of $2^{\circ}, 3^{\circ}$, and $5^{\circ}$. Four test fields $(12 \mathrm{~m} \times 3.5 \mathrm{~m})$ were set up in each test area, and wheat, rape, pasture and salvia were planted in sequence. The model design is presented in Fig. 1. Wheat and rapeseed planting was taken as an example and were planted in mid-October each year, and harvested at the end of May of the following year. Fertilizer types used were urea (nitrogen content is about $46.4 \%$ ), diammonium phosphate (nitrogen content $16 \%$, effective phosphorus content $44 \%$, calculated as $\left.\mathrm{P}_{2} \mathrm{O}_{5}\right)$ and potassium sulfate $\left(\mathrm{K}_{2} \mathrm{O}\right.$ content $\left.52 \%\right)$. All phosphate fertilizer $\left(1.5 \mathrm{~kg} / \mathrm{km}^{2}\right.$, calculated as $\left.\mathrm{P}_{2} \mathrm{O}_{5}\right)$ and potash fertilizer $\left(2.25 \mathrm{~kg} / \mathrm{km}^{2}\right.$, calculated as $\mathrm{K}_{2} \mathrm{O}$ ) were used as base fertilizer, and $60-70 \%$ nitrogen fertilizer was used as base fertilizer (calculated as $65 \%$ of all pure $\mathrm{N}$ fertilizer $2.78 \mathrm{~kg} / \mathrm{km}^{2}, 1.80 \mathrm{~kg} / \mathrm{km}^{2}$, counted by N). One to two days before planting, the three kinds of fertilizers were weighed according to the required amount of each plot and mixed them evenly, they were sprinked evenly on the soil surface, and then the fertilizer was properly raked to mix the topsoil. The top dressing time of rape and wheat 
was the same. The 30-40\% of the nitrogen fertilizer during the whole growth period of wheat (calculated as $35 \%$ of the total $\mathrm{N}$ fertilizer $2.78,0.98 \mathrm{~kg} / \mathrm{k} \mathrm{m}{ }^{2}$, calculated as $\mathrm{N}$ ) was applied in the jointing stage in combination with irrigation. The basic physical and chemical properties of the soil were organic matter $8.5 \mathrm{~g} / \mathrm{kg}$, total nitrogen $0.38 \mathrm{~g} / \mathrm{kg}$, available phosphorus $20.56 \mathrm{mg} / \mathrm{kg}$, available potassium $130.25 \mathrm{mg} / \mathrm{kg}, \mathrm{pH} 7.5$, and the soil texture was sandy loam.

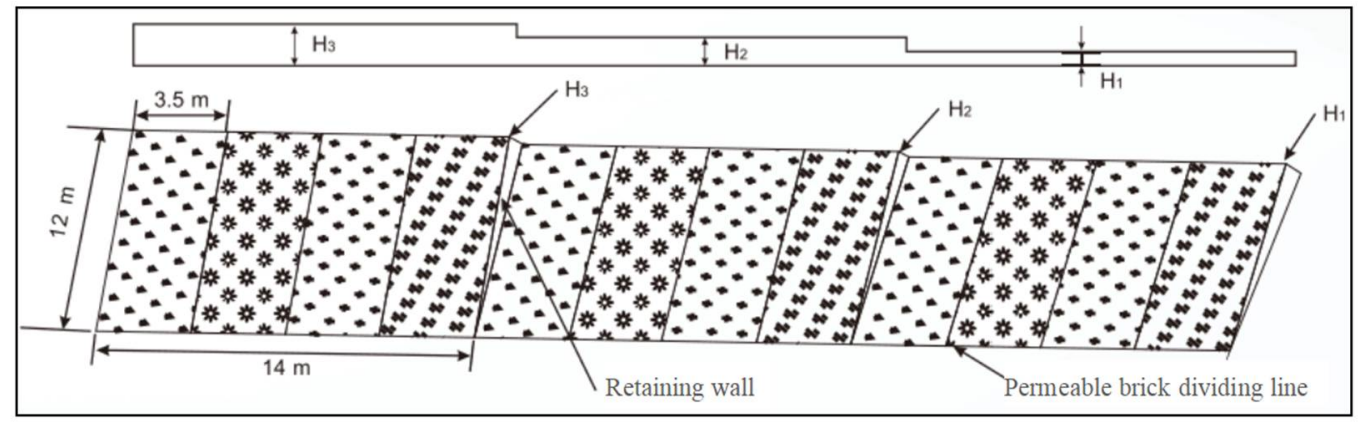

Fig. 1. Design drawing of sloping farmland model. The heights $\mathrm{H} 1, \mathrm{H} 2$, and $\mathrm{H} 3$ are $0.4 \mathrm{~m}, 0.73 \mathrm{~m}$, and $1.1 \mathrm{~m}$ respectively; the slopes of the three test areas from left to right are $5^{\circ}, 3^{\circ}$ and $2^{\circ}$.

Every year at the end of May, soil samples of each slope were collected after the crops were harvested. Each test plot was divided into three parts: upper, middle and lower samples, and each part was evenly collected by the five-point method and mixed into one sample. The soil samples were passed through a $2 \mathrm{~mm}$ sieve to remove animal and plant residues and gravel, and then the soil was air-dried indoors and passed through a $1 \mathrm{~mm}$ sieve and $0.149 \mathrm{~mm}$ sieve to determine soil physical and chemical properties. Soil organic matter (SOM) and total nitrogen (TN) were measured by potassium dichromate external heating method (Tyurin 1931) and semi-micro Kjeldahl method, available potassium (AP) and available phosphorus (AK) were determined by $\mathrm{NaHCO}_{3}$-spectrophotometer colorimetric method (Bao 2000) and $\mathrm{NH}_{4} \mathrm{OAc}$-flame photometer method (Ahaiwe et al. 2010), respectively . The texture of the soil was measured through a $2 \mathrm{~mm}$ sieve with a Malvern laser particle size analyzer (MS2000, UK).

Soil erodibility reflects the sensitivity of soil to the separation and transport of erosion forces (Bouyoucos 1935).The higher the soil erodibility factor (K), the weaker the soil erosion resistance, and the lower the K-corrosion resistance $(\mathrm{K})$ value, the stronger the soil erosion resistance (Liu et al. 1999). K was calculated as follows (Liu et al. 2021).

$\mathrm{K}=\left\{0.2+0.3 \exp \left[-0.0256 S_{a}\left(1-\frac{1-S_{i}}{100}\right)\right]\right\}\left(\frac{S_{i}}{C_{l}+S_{i}}\right)^{0.3}\left\{\frac{1.0-0.25 \mathrm{C}}{[C+\exp (3.72-295 C)]}\right\} \frac{1.0-0.7 S_{n}}{\left[S_{n}+\exp \left(-5.51+229 S_{n}\right)\right]}$

Among them, K-corrosion resistance; $\mathrm{S}_{\mathrm{a}}$-sand content $(2-0.05 \mathrm{~mm}) ; \mathrm{S}_{\mathrm{i}}$-powder content $(0.05-$ $0.002 \mathrm{~mm}) ; \mathrm{C}_{1}$-clay content $(<0.002 \mathrm{~mm}) ; \mathrm{S}_{\mathrm{n}}=1-\mathrm{S}_{\mathrm{a}} / 100 ;$ C-soil organic carbon content.

The test data were statistically analyzed using DPS18.10 and Excel 2003 software. The analysis of variance of the two-factor repetitive module in DPS was adopted for the analysis of correlation the Person analysis method was adopted, and for the significance test Duncan's new multiple range method was adopted. 


\section{Results and Discussion}

SOM is an important component of soil and a relatively active part of soil solid phase, which is usually used as an important index to measure the level of soil fertility (Yan et al. 2020). In the present study, there was no significant difference in SOM content under different planting patterns and different slope treatments, but there were still differences. The average SOM of wheat-grown sloping farmland was $9.54 \mathrm{~g} / \mathrm{kg}$, and the content of $5^{\circ}$ treatment was higher, which increased by 7.19 and $17.33 \%$ compared with $2^{\circ}$ and $3^{\circ}$ treatments, respectively. The average SOM of rapeseed sloping farmland was $10.72 \mathrm{~g} / \mathrm{kg}$, among which the content of $3^{\circ}$ treatment was higher, which increased by 5.98 and $12.15 \%$ compared with $2^{\circ}$ and $5^{\circ}$ treatments, respectively (Fig. 2A). It might be because the root system of rape was more developed than that of wheat, which promoted the accumulation of soil nutrients. TN was significantly different under different crop planting modes $(\mathrm{P}<0.05)$, and the TN content of rape planting was significantly increased by $29.09 \%$ compared with wheat planting. The $\mathrm{TN}$ of $5^{\circ}$ treatment under wheat planting increased by 62.50 and $10.17 \%$ compared with $2^{\circ}$ and $3^{\circ}$ treatments, respectively. Compared with $3^{\circ}$ and $5^{\circ}$ treatments, the $\mathrm{TN}$ of rapeseed planting under $2^{\circ}$ increased by 37.93 and $6.67 \%$, respectively. In the wheat and rapeseed planting modes, the SOM and TN content in both treatments at $5^{\circ}$ was higher (Fig. 2B). The reason is that the $5^{\circ}$ slope was larger and the terrain was higher, and the phenomenon of runoff were more obvious, which made the nutrient content at the lower and middle of the slope more concentrated and the soil layer thickened (Renata et al. 2019). It can be seen that rape planting is beneficial to the accumulation of SOM and TN, and nutrient accumulation was more obvious under $5^{\circ}$ treatment.
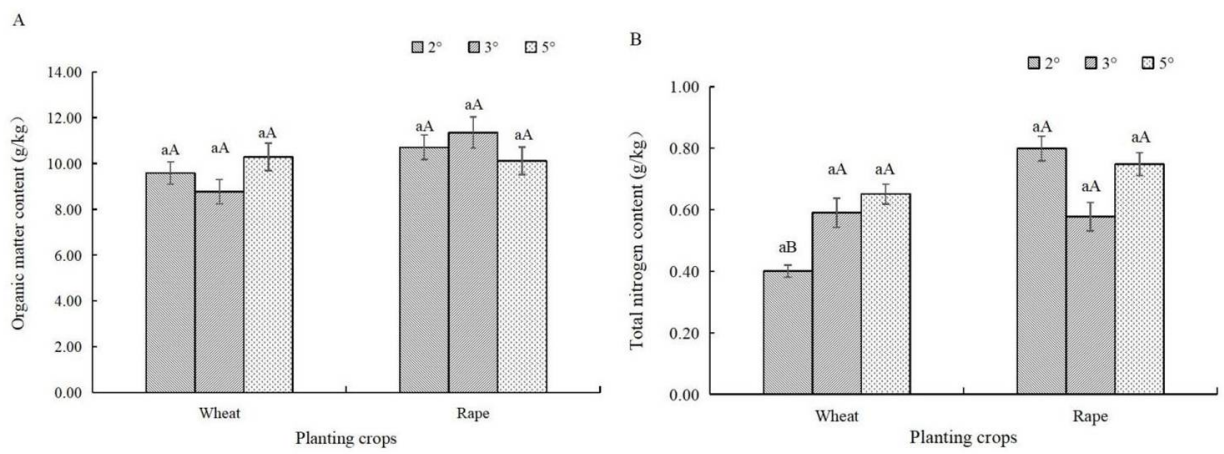

Fig. 2. Effects of different crop cultivating on soil organic matter (A) and total nitrogen (B) contents in sloping farmland. Lowercase letters indicate the significance between different slopes, and uppercase letters indicate the differences between crop planting methods under the same slope $(\mathrm{p}<0.05)$.

Phosphorus transport in soil is a relatively slow process. The results showed that there was no significant difference in AP content under different slopes and planting modes, but there was an obvious gradient trend. The AP content in each outliving mode increased with the increase of slope, and the AP content in wheat cultivating increased by $11.58 \%$ compared with rape planting (Fig. 3A). The AK content is significantly different among different cultivating modes. Compared with wheat, rapeseed planting increased the AK content by $16.59 \%$, which was more obvious in the $2^{\circ}$ and $5^{\circ}$ treatments, because the rapeseed has a greater demand for potassium at each growth stage and has a strong enrichment effect. In the wheat planting mode, the AK content of the $3^{\circ}$ treatment was significantly higher than that of other treatments. Under the rape planting mode, there was no significant difference in the AK content of each slope treatment. The average AK content was higher when treated with $3^{\circ}$ (Fig. 3B). 

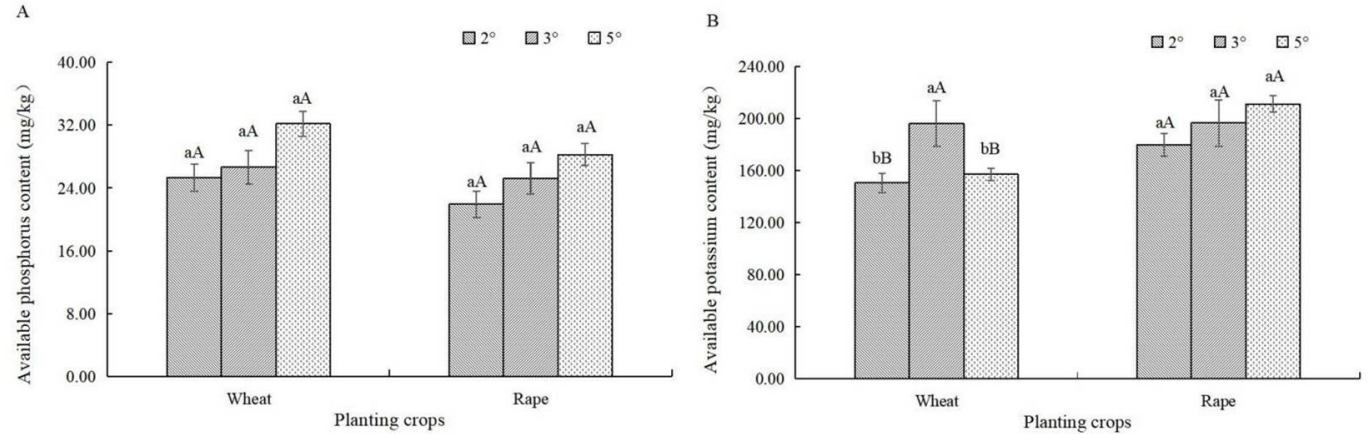

Fig. 3. The effect of cultivating different crops on the content of available phosphorus (A) and available potassium (B) in sloping farmland.

Under the wheat planting mode, there was no significant difference in the soil of different particle sizes among different slopes, and the soil texture was all sandy loam. Under the rape planting mode, the sand content of the $5^{\circ}$ slope land was significantly higher than that of $3^{\circ}$, and the silt content was similar to its changing trend, and the soil texture in the $3^{\circ}$ slope land was silt loam (Table 1). Soil anti-erodibility refers to the ability of soil to resist its suspension and decomposition by runoff, and the development of soil erosion is closely related to it. The present study shows that the erodibility of $2^{\circ}$ sloping farmland was the largest under different planting patterns, indicating that the $2^{\circ}$ sloping farmland has the weakest ability to resist soil erosion. Compared with planting wheat, the soil erodibility of rapeseed was reduced by $0.84 \%$, and in the rape planting mode, the soil erodibility decreased with the increase of slope (Fig. 4). It shows that rapeseed planting can increase the erodibility of sloping farmland, the greater the slope, the stronger the erosion resistance. Increase in soil organic matter content of $5^{\circ}$ sloping farmland may improve soil structure, increase soil porosity, increase soil permeability and water holding capacity, and enhance soil erosion resistance (Li et al. 2013).

Table 1. Effects of cultivating different crops on the texture in sloping farmland.

\begin{tabular}{llllll}
\hline $\begin{array}{l}\text { Planting } \\
\text { crops }\end{array}$ & Slope & Sand $(50 \sim 2000 \mu \mathrm{m}, \%)$ & Silt $(2 \sim 50 \mu \mathrm{m}, \%)$ & Clay $(0 \sim 2 \mu \mathrm{m}, \%)$ & Texture \\
\hline Wheat & $2^{\circ}$ & $51.93 \pm 3.11 \mathrm{aA}$ & $47.89 \pm 3.06 \mathrm{aA}$ & $0.18 \pm 0.01 \mathrm{aA}$ & Sandy loam \\
& $3^{\circ}$ & $53.73 \pm 1.57 \mathrm{aA}$ & $46.10 \pm 1.57 \mathrm{aB}$ & $0.17 \pm 0.06 \mathrm{aB}$ & Sandy loam \\
& $5^{\circ}$ & $52.33 \pm 1.58 \mathrm{aA}$ & $47.48 \pm 1.47 \mathrm{aA}$ & $0.19 \pm 0.06 \mathrm{aA}$ & Sandy loam \\
Rape & $2^{\circ}$ & $51.00 \pm 1.08 \mathrm{abA}$ & $48.72 \pm 1.13 \mathrm{abA}$ & $0.28 \pm 0.02 \mathrm{aA}$ & Sandy loam \\
& $3^{\circ}$ & $47.45 \pm 3.23 \mathrm{bB}$ & $52.16 \pm 3.23 \mathrm{aA}$ & $0.39 \pm 0.06 \mathrm{aA}$ & Silt loam \\
& $5^{\circ}$ & $52.65 \pm 2.02 \mathrm{aA}$ & $47.05 \pm 1.93 \mathrm{bA}$ & $0.30 \pm 0.01 \mathrm{aA}$ & Sandy loam \\
\hline
\end{tabular}

Both slope and planting pattern have a significant impact on crop yield. The yield of wheat increased with the increase of slope. There was no significant difference between $3^{\circ}$ and $5^{\circ}$ slope farmland, but both were significantly higher than the $2^{\circ}$ treatment, and the increase rates were 32.72 and $48.61 \%$, respectively. The yield of rapeseed was highest in $5^{\circ}$ sloping farmland, followed by $2^{\circ}$ sloping farmland, and $3^{\circ}$ had the lowest yield, but there was no significant difference between slope treatments (Fig. 5). Under the wheat planting model, soil erodibility and 
clay content are positively correlated, and the greater the slope, the stronger the correlation. Under the rape planting mode, the soil erodibility was only significantly negatively correlated with the organic matter content of the $3^{\circ}$ treatment (Table 2).

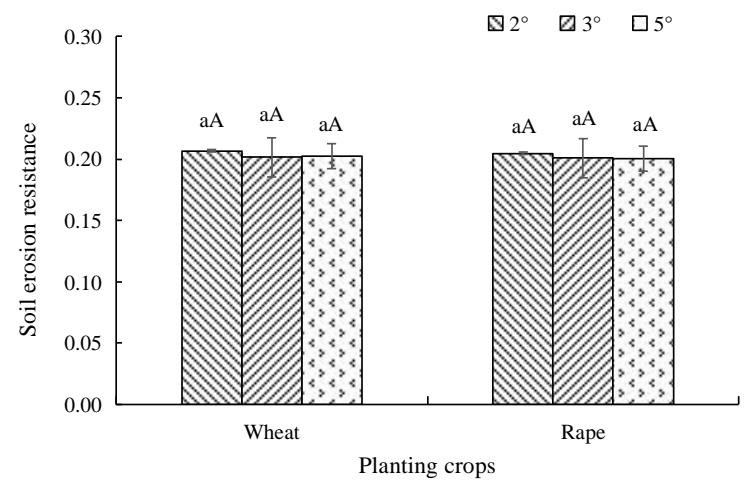

Fig. 4. Effect of planting different crops on the soil erosion resistance in sloping farmland.

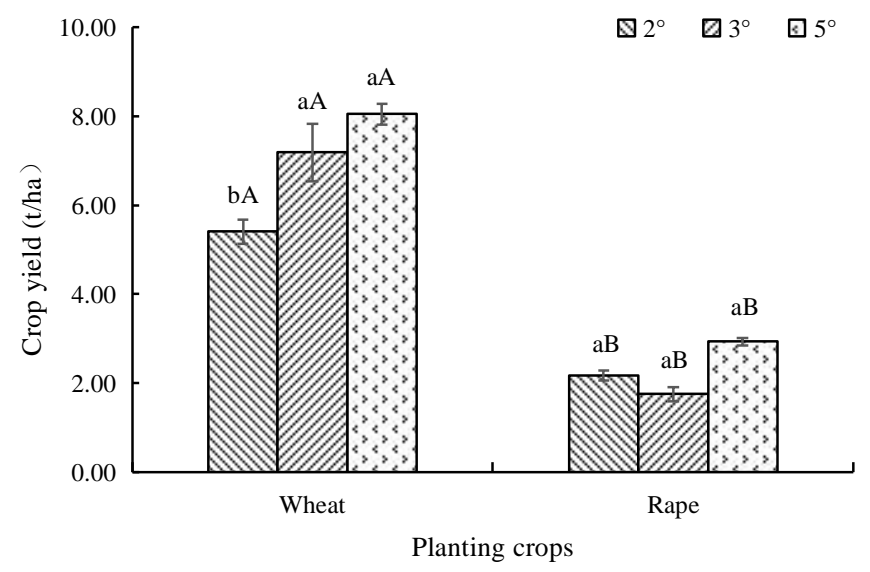

Fig. 5. The crop yield of sloping farmland soil under different cultivation patterns.

Table 2.Relationship between soil erodibility and soil physical and chemical properties and crop yield.

\begin{tabular}{lllllllll}
\hline crops & Slope & $\begin{array}{l}\text { Organic } \\
\text { matter }\end{array}$ & $\begin{array}{l}\text { Total } \\
\text { nitrogen }\end{array}$ & $\begin{array}{l}\text { Available } \\
\text { phosphorus }\end{array}$ & $\begin{array}{l}\text { Available } \\
\text { potassium }\end{array}$ & Sand & Clay & Yield \\
\hline Wheat & $2^{\circ}$ & -0.4429 & 0.5873 & -0.9887 & 0.2903 & -0.1051 & 0.2440 & 0.9770 \\
& $3^{\circ}$ & -0.8340 & -0.5797 & -0.2513 & -0.9342 & 0.5282 & 0.5797 & 0.9180 \\
& $5^{\circ}$ & -0.9950 & 0.7486 & -0.6323 & -0.9946 & -0.9522 & $0.9999 * *$ & -0.3289 \\
Rape & $2^{\circ}$ & -0.0567 & 0.2540 & 0.0997 & 0.4425 & 0.1512 & 0.3842 & 0.0970 \\
& $3^{\circ}$ & $-0.9993^{*}$ & -0.4918 & -0.7553 & -0.3436 & 0.3216 & 0.0000 & 0.1396 \\
& $5^{\circ}$ & 0.9493 & 0.9584 & 0.9245 & 0.6018 & 0.2986 & 0.2186 & -0.2617 \\
\hline
\end{tabular}

*Means that the correlation reaches a significant level $(\mathrm{p}<0.05)$, and $* *$ means that the correlation reaches a very significant level $(\mathrm{p}<0.01)$. 
The cultivation of different crops and the treatment of different slopes all affect the physical and chemical properties of the soil. Rape planting has effectively increased the nutrient content of sloping farmland, with organic matter, total nitrogen, and available potassium being the most prominent, and the soil texture has developed benign to silt loam.Under rape planting, the greater the slope, the stronger the soil erosion resistance, and it increased with the increase of organic matter content. It may said that soil erosion resistance has an important influence on the development of soil erosion.

\section{Acknowledgements}

This study was financially supported by Shaanxi Provincial Natural Science Basic Research Program (2021JZ-57), Shaanxi Province Innovative Talents Promotion Plan Young Science and Technology Rising Star Project (2021KJXX-88), Technology Innovation Center for Land Engineering and Human Settlements, Shaanxi Land Engineering Construction Group Co.,Ltd. and Xi'an Jiaotong University (2021WHZ0087, 2021WHZ0093).

\section{References}

Ahaiwe MO, Nwaigbo LC and Nwaigbo AO 2010. Influence of plant prunings on soil properties and yield of yam minisett. J. Agr. Soc. Res. 10: 172-177.

Bircher P, Liniger HP and Prasuhn V 2019. Comparing different multiple flow algorithms to calculate RUSLE factors of slope length (L) and slope steepness (S) in Switzerland. Geomorph. 346: 106850.

Bouyoucos GJ 1935. The clay ratio as a criterion of susceptibility of soils to erosion. J. Am. Soc. Agron. 27(9):738-741.

Bao SD 2000. Soil agrochemical analysis (3rd edition). Beijing: China Agricultural Press, 30-34.

Cerdà A, Terol E and Daliakopoulos IN 2021. Weed cover controls soil and water losses in rainfed olive groves in Sierra de Enguera, eastern Iberian Peninsula. J. Environ. Manage. 290: 112516.

Du XL and Du XR 2013.The effect of soil erosion on the physical fertility of black soil.Jilin Water Resour.5: 5-7.

Guo SL, Dang TH and Hao MD 2003. Distribution characteristics of mineral nitrogen in soil profile of gully slope land in the gully area of the Loess Plateau. J. Soil Water Conser. 2: 31-33+66.

Li CH, Zhu SJ and Chen YM 2013.Effect of forage hedgerows on soil erosion resistance of slope farmland in loess hilly region. J. Northwest For. U. 28(5): 41-46.

Li ZG and Wang YS 2020.The main objectives, tasks and realization methods of comprehensive supervision of soil erosion in my country in the new era.Sci. Soil Water Conser.18(6): 99-104.

Liu L, Guo YF, Yao YF, Liu XY and Qi W 2021.The spatial distribution and dynamic changes of soil erosion in the upper reaches of the top ten holes.Res. SoilWater Conser.28(4): 34-41+47.

Liu BY, Zhang KL, Jiao JY 1999.Soil erodibility and its application in erosion prediction. J. Nat. Resour.14(4):345-350.

Meng H, Gao YF, He J, Qi YS and Hang L 2021. Microbially induced carbonate precipitation for wind erosion control of desert soil: Field-scale tests. Geoderma 383: 114723.

Nearing MA, Jetten V, Baffaut C, Cerdan O, Couturier A, Hernandez M, Le Bissonnais Y, Nichols MH, Nunes JP, Renschler CS, Souchère V and van Oost K 2005. Modeling response of soil erosion and runoff to changes in precipitation and cover. Catena 61(2): 131-154.

QuijanoL, Kuhn NJ and Navas A 2019. Soil particle size distribution and induced soil carbon transport by ephemeral gully erosion in Mediterranean mountain arable land. Earth Surf.Proc. Land.44(14): 27412751.

Renata D, Petr F, Lucie J and Martina J 2019. Experimental evaluation of the potential of arbuscularmycorrhiza to modify nutrient leaching in three arable soils located on one slope. Appl. Soil Ecol. 143:116-125. 
Siraj B and Jemal A 2017. Effect of maize/haricot bean intercropping on soil fertility improvement under different tied ridges and planting methods, southeast ethiopia. J. Geosci. Environ. Pro.5(8): 63-70.

Tyurin IV 1931. A new modification of the volumetric method of determining soil organic matter by means of chromic acid. Pochvovedenie 6: 36-47.

Wen LL, Wang JH, Ren M, Fan JR, Bai JH and Shang JX 2021.Effectiveness of comprehensive control of soil and water loss in the black soil region of northeast China.Soil Water Conserv. China 6: 4-7.

Xiang W, Si BC, Li M, Li H, Lu YW, Zhao MH and Feng H 2021. Stable isotopes of deep soil water retain long-term evaporation loss on China's Loess Plateau. Sci.Total Environ. 784: 147153-147153.

Yan LL, Liu C, Zhang YD, Liu S and Zhang Y 2020. Effects of C/N ratio variation in swine biogas slurry on soil dissolved organic matter: Content and fluorescence characteristics. Ecotox. Environ. Safe. 209: 111804.

Zhang PH, Wang $\mathrm{J}$ and Ma F 2014.The influence of winter wheat root system on soil erosion resistance.China Rural Water Hydro. 7: 7-10.

Zhang SS, Zhou ZF, Sun XT, Feng Q and Chen Q 2017.Study on the relationship between rocky desertification and soil erosion in karst mountainous areas based on slope grades-Taking Pan County, Guizhou Province as an example.J. Soil Water Conser. 31(2): 79-86.

(Manuscript received on 9 July, 2021, revised on 6 October, 2021) 